\title{
Identifying the Effect of Financial and Market Access on Micro-Enterprise Performance in Indonesia
}

\author{
Vidyana Putri Hidayati ${ }^{1,}$ Teguh Dartanto ${ }^{2 *}$ \\ ${ }^{1}$ Department of Economics, Universitas Indoensia, Jakarta, Indonesia \\ ${ }^{2}$ Department of Economics, Universitas Indoensia, Jakarta, Indonesia \\ *Corresponding author. Email: tdartanto@yahoo.com
}

\begin{abstract}
Micro-enterprises are the most dominant business type in Indonesia, and their growth leads our economy. However, according to various empirical studies in several developing countries, micro-enterprises still face difficulties in financial and market access. Therefore, this study discusses those factors on micro-enterprise performance in Indonesia using data panel analysis on data from the Indonesian Family Life Survey. The results of this study indicate micro-enterprises located in regions having adequate infrastructure that obtain capital loans from formal financial institutions demonstrate better performance.
\end{abstract}

Keywords: Financial Access, Market Access, Enterprise Performance, Micro-Enterprises, Indonesian Family Life Survey

\section{INTRODUCTION}

Micro, small, and medium enterprises (MSME) dominate Indonesia"s economy. The Indonesian Ministry of Cooperatives and MSMEs (2017) stated that $99.99 \%$ of all Indonesian enterprises were MSMEs, of which, 98.7\% were "micro." It is therefore important for stakeholders and the government to support their growth and prosperity. Unfortunately, micro-enterprises in Indonesia still face obstacles to their growth. The Bank of Indonesia (2016) mentioned that there were internal and external factors hampering business growth, and one of them was limited access to finance and infrastructure. $60-70 \%$ of Indonesian enterprises lack access to proper financing. Thus, enterprises tend to rely on internal financing as sources of capital. The latest results from the Indonesia Family Life Survey (IFLS) in 2014 revealed that most businesses built capital from their own savings with additional loans from families.

Several empirical studies have examined the relationship of financial access to enterprises performance in Indonesia. Riwayati (2017) studied MSMEs in Magelang, showing that financial inclusion had a positive correlation to business performance. However, access to credit was not a significant factor on MSME performance in East Java (Mcpherson \& Rous, 2010). However, these findings only revealed correlations between credit access and business performance, because both studies used cross-sectional data analysis, measuring access to credit obtained by entrepreneurs. Notably, access also involves other proxies.

In terms of infrastructure, the Bank of Indonesia (2017) revealed that inadequate facilities and infrastructure could slow down MSME performance and limit market access. Limited market access can also affect business performance, because it drives higher transaction costs (OECD, 2017). Another empirical study explained that non-agricultural enterprises in rural Indonesia tended to have lower income if they were located in areas lacking paved roads far from cities (Gibson \& Olivia, 2010).

Thus far, we can conclude that at least two factors affect the growth and performance of micro-enterprises in Indonesia: financial and market access. This is consistent with the results of the 2018 Survey of Entrepreneurs and MSMEs in Indonesia, which revealed that there were three main factors inhibiting business growth: financing, marketing, and physical infrastructure (A.P.F. of Canada, 
2018). Nevertheless, there is still debate about the influence of these two factors. Therefore, more research is needed to identify the effects of both factors on microenterprise performance in Indonesia, ostensibly using more observations and more relevant proxies.

\section{LITERATURE REVIEW}

\subsection{Definition of Micro-enterprises and Enterprise Performance}

Each country and institution has its own understanding of the scope and meaning of MSMEs based on various criteria. One criterion is the number of workers. Notably, micro-enterprises typically have 1-9 workers; small enterprises have 10-49; and medium-sized enterprises have 50-249 (Mirmulstein, 2014).

In an entrepreneurial paradigm, enterprise performance is characterized by growth (Murphy, Trailer, \& Hill, 1996; Carton, 2004). Enterprise growth can be categorized into two types: qualitative and qualitative. Quantitative performance can be measured by growth in sales, capital, labor, markets, and profits (Murphy, Trailer, \& Hill, 1996; Carton \& Hofer, 2010; Hudson, Smart, \& Bourne, 2001). Qualitative growth can be measured by product quality, managerial quality, or customer services (Murphy, Trailer, \& Hill, 1996; Carton \& Hofer, 2010).

External factors include government policies, socio economic and cultural conditions, and the role of related institutions (Hudson, Smart, \& Bourne, 2001). The OECD presented a conceptual framework for MSME performance that leveraged four factors influencing performance: regulation and institutions, market access, business culture, and access to resources (OECD, 2017).

\subsection{Financial and Market Access}

This study leverages two factors: financial access (e.g., resources) and market access (e.g., infrastructure). Financial access implies the absence of price or non-price barriers characterized by the supply of financial services. The use of financial services is included in the concept of access, because it is based on supply and demand (Demirgüç-Kun, Beck, \& Honohan, 2008). Meanwhile, the proxy for measuring market access is the quantity and quality of infrastructure. OECD (2017) revealed that the existence of basic physical infrastructure (e.g., roads, terminals, stations, ports, and electricity) could increase business competition and facilitate market entry at competitive prices, because it improves logistics (OECD, 2017).
This study uses other factors that support the analysis: enterprise location and household characteristics of micro enterprise owners. Location identifies where activities are carried out (e.g., urban or rural) (Sridhar \& Wan, 2010). According to Nichter and Goldmark (2009), individual characteristics of business owners and households (e.g., gender and level of education) are important factors to the growth of MSMEs.

\section{METHODOLOGY AND DATA}

\subsection{Data and Empirical Model}

The data used in this study came from the survey results of Indonesian Family Life Surveys 4 and 5, using a 2-year panel data analysis of 2007 and2014. This study adopted a model from Gibson and Olivia (2010) and McPherson and Rous (2010), where

$$
\begin{array}{ll}
\text { EnterpriseGrowth }_{i, j}=\quad & \alpha+\beta_{1 . \text { Credit }_{i, j}+} \\
& \beta_{2} \text { Infrastructure }_{i, j}+ \\
& \beta_{3} \text { Location }_{i, j}+ \\
& \beta_{4} \text { HHCharacteristic }_{i, j}+e_{i, j}
\end{array}
$$

where EnterpriseGrowth is the dependent variable consisting of profit, number of workers, and number of sales. CREDIT, INFRASTRUCTURE, LOCATION, and HH CHARACTERISTICS are independent variables. Thus, the empirical model used in this study is as follows:

$$
\begin{aligned}
& \text { EnterprisePerformance }_{, t}=\alpha+\beta 1 . \text { FinancialAccess }_{i, t} \\
& +\beta 2 \text { MarketAccessi, } t+\beta 3 \text { Location }_{i, t} \\
& +\beta 4 \mathrm{HHCharacteristic} \mathrm{i}_{\mathrm{i}, \mathrm{t}}+\mathrm{e}_{\mathrm{i}, \mathrm{t}}
\end{aligned}
$$

where EnterprisePerformance includes profit, and FinancialAccess is the distance to formal financial institutions, suppliers of business credit, and ownership status of credit. MarketAccess is the distance to public transportation and road quality. The location is the business is a location variable, and HHCharacteristics consists of the number of household members, including age, gender, and education level of the head of the household.

\subsection{Model Estimation}

Before conducting a regression analysis, we must test the estimation of the model to get the most appropriate model estimate. Regression analysis using panel data can be performed with three estimation methods: pooled least square, fixed effect (FE), and random effect. To estimate the best model, this research uses the Hausman test. Based on test results, the best model estimation is found to be the 
FE model. The regression model also implies the year effect.

Table 1. Variables

\begin{tabular}{|c|c|c|c|}
\hline Category & Name & Description & $\begin{array}{c}\text { Expected } \\
\text { Sign }\end{array}$ \\
\hline \multicolumn{4}{|c|}{ Dependent Variable } \\
\hline $\begin{array}{l}\text { Enter- } \\
\text { prise } \\
\text { Perfor- } \\
\text { mance }\end{array}$ & profit & Profit, in log & \\
\hline \multicolumn{4}{|c|}{ Independent Variable } \\
\hline \multirow[t]{3}{*}{$\begin{array}{l}\text { Finan- } \\
\text { cial } \\
\text { Access }\end{array}$} & credit & $\begin{array}{c}\text { The credit } \\
\text { ownership } \\
0=\text { Does not } \\
\text { have credit, } \\
1=\text { does have credit }\end{array}$ & $(+)$ \\
\hline & distance & $\begin{array}{l}\text { The distance to the } \\
\text { nearest } \\
\text { formal financial } \\
\text { institution, in log }\end{array}$ & $(-)$ \\
\hline & $\begin{array}{l}\text { Credits } \\
\text { upply }\end{array}$ & $\begin{array}{l}\text { The supply of formal } \\
\text { business credit, } \\
0=\text { not available } \\
1=\text { available }\end{array}$ & $(+)$ \\
\hline \multirow[t]{2}{*}{$\begin{array}{l}\text { Market } \\
\text { Access }\end{array}$} & $\begin{array}{c}\text { distance } \\
\text { _trans }\end{array}$ & $\begin{array}{l}\text { The distance to public } \\
\text { transport } \\
\text { facilities (train station/ } \\
\text { port/ bus station), in log }\end{array}$ & $(-)$ \\
\hline & $\begin{array}{l}\text { Road } \\
\text { quality }\end{array}$ & $\begin{array}{l}\text { Road quality, } \\
0=\text { not paved, } \\
1=\text { paved }\end{array}$ & $(+)$ \\
\hline
\end{tabular}

\section{RESULT}

\subsection{Descriptive Statistics}

Table II shows that there is an imbalance in the amount of profit among micro-enterprises, where the average profit of household businesses is 13.6 million Rupiah, but the maximum profit is 100 million Rupiah. This implies that there are many businesses that get smallto-no profit. In terms of market access, the greatest distance to public transportation is $110 \mathrm{~km}$, whereas the average distance is relatively far at $11 \mathrm{~km}$. However, there are enterprises that take the shortest distance to get to public transportation.
Table II. Continuous Variable Statistics

\begin{tabular}{|l|c|l|l|l|l|}
\hline $\begin{array}{c}\text { Varia- } \\
\text { bles }\end{array}$ & Obs & Mean & St. Dev & Min & Max \\
\hline Profit & 2,586 & $\begin{array}{c}13,600, \\
000\end{array}$ & $\begin{array}{c}35,500, \\
000\end{array}$ & 0 & $\begin{array}{c}100,00 \\
0,000\end{array}$ \\
\hline Distance & 2,586 & $\begin{array}{l}7,009, \\
946\end{array}$ & 859,231 & 0,2 & 80 \\
\hline $\begin{array}{l}\text { Distance } \\
\text { trans }\end{array}$ & 2,586 & $\begin{array}{c}1,111, \\
178\end{array}$ & $\begin{array}{l}5,428, \\
133\end{array}$ & 0,1 & 110 \\
\hline
\end{tabular}

(source: IFLS, author"s calculation)

most enterprise areas. Nonetheless, the availability of formal business credit can be said cover nearly all enterprise areas. However, only a small proportion obtain formal loans (see Fig. I). This indicates that financial access from the supply side makes business credit relatively available in most household businesses, but the majority of enterprise do not benefit from that access.

In terms of road infrastructure, most enterprise areas are built with adequate access to quality roads. Most enterprise areas are traversed by paved roads (95\%), but the distribution of enterprises in the research is evenly distributed, such that $\sim 58 \%$ are in urban areas and $\sim 42 \%$ are in rural areas.

In the category of financial access variables, there are three: distance to formal financial institutions; use of formal loans; and availability of business credit. The variable of business credit availability has an estimated positive significant effect on business profit, meaning that a business has a greater profit if the surrounding financial institutions provide business credit services. The variable use of formal loans has a positive coefficient, businesses obtaining capital from financial institutions have profit growth, and their number of workers is greater. The regression results reveal a significant value. Thus, it statistically illustrates the relationship between business credit use and performance is positive. This is consistent with the expected results.

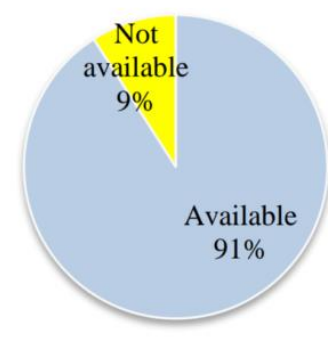

Figure I Supply of Business Credit. 


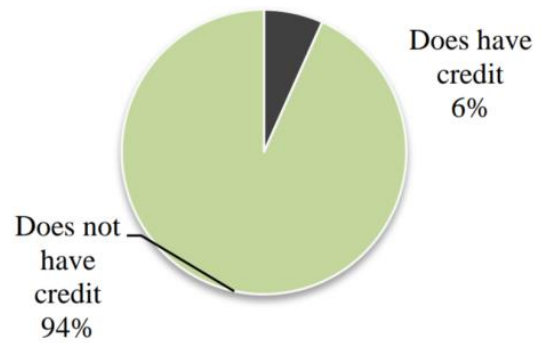

Figure I1 Status of Credit Ownership

\subsection{Regression Results: Effect of Financial Access on Micro-enterprises Performance}

The distance to formal financial institutions is statistically insignificant, rendering the variable incapable of explaining the estimated relationship to business performance. This indicates that financial access and inclusion can affect the performance of a business if the business actor has succeeded in obtaining available business credit services. Thus, the affordability of financial institutions is insufficient to create growth. Financial institutions should, therefore, provide services that can support the community, especially small business actors.

The availability of business credit is included in the supply of access or financial inclusion. Thus, it is expected to encourage business performance and growth. Based on the availability of business credit services, entrepreneurs are encouraged to apply for credit. Especially when considering that a lack of funding is a hard obstacle for a business. The results of the survey from the International Finance Cooperation (2017) stated that $26 \%$ of MSMEs in Indonesia claimed that financial limitations were a major obstacle to growth. Therefore, obtaining external financing from related institutions can be a solution, because commercial banks dominate the distribution of business loans. The portion of business loans distributed by commercial banks recently reached $60 \%$ (International Finance Corporation, 2017).

Table 1. Variables

\begin{tabular}{|c|c|c|c|c|}
\hline PROFIT & (1) & (2) & (3) & (4) \\
\hline DISTANCE TO FINANCIAL INSTITUTIONS & -0.0455 & -0.101 & -0.0890 & -0.114 \\
\hline & $(0.113)$ & $(0.112)$ & $(0.114)$ & $(0.113)$ \\
\hline SUPPLY OF BUSINESS CREDIT & $0.326 * *$ & 0.240 & $0.307 *$ & 0.237 \\
\hline$(0=$ NOT AVAILABLE, $1=$ AVAILABLE) & $(0.161)$ & $(0.159)$ & $(0.160)$ & $(0.159)$ \\
\hline STATUS OF CREDIT OWNERSHIP & $0.767 * * *$ & $0.547 * *$ & $0.691 * * *$ & $0.542 * *$ \\
\hline$(0=$ DOES NOT HAVE CREDIT, $1=$ CREDIT $)$ & $(0.233)$ & $(0.232)$ & $(0.233)$ & $(0.233)$ \\
\hline ROAD QUALITY & $0.389 *$ & 0.262 & 0.293 & 0.234 \\
\hline$(0=$ NOT PAVED, $1=$ PAVED $)$ & $(0.203)$ & $(0.201)$ & $(0.203)$ & $(0.201)$ \\
\hline DISTANCE TO PUBLIC TRANSPORT FACILITIES & -0.0189 & -0.0715 & -0.0298 & -0.0699 \\
\hline & $(0.0766)$ & $(0.0760)$ & $(0.0761)$ & $(0.0760)$ \\
\hline TYPE OF REGION & & & 0.0405 & -0.214 \\
\hline
\end{tabular}




\begin{tabular}{|c|c|c|c|c|}
\hline$(0=$ RURAL, $1=$ URBAN $)$ & & & $(0.213)$ & $(0.219)$ \\
\hline \multirow[t]{2}{*}{ NUMBER OF HOUSEHOLD MEMBERS } & & & 0.194 & 0.267 \\
\hline & & & $(0.210)$ & $(0.209)$ \\
\hline \multicolumn{5}{|l|}{ CHARACTERISTIC OF HEAD OF HOUSEHOLD } \\
\hline \multirow[t]{2}{*}{ AGE OF HEAD OF HOUSEHOLD } & & & $1.188 * * *$ & 0.428 \\
\hline & & & $(0.330)$ & $(0.370)$ \\
\hline SEX OF HEAD OF HOUSEHOLD & & & 0.165 & 0.217 \\
\hline$(0=$ WOMAN, $1=$ MAN $)$ & & & $(0.209)$ & $(0.208)$ \\
\hline ELEMENTARY-SCHOOL GRADUATE & & & -0.194 & -0.343 \\
\hline$(0=$ OTHERS, $1=$ ES GRADUATE $)$ & & & $(0.264)$ & $(0.264)$ \\
\hline MIDDLE-SCHOOL GRADUATE & & & 0.0640 & -0.275 \\
\hline$(0=$ OTHERS, $1=$ MS GRADUATE $)$ & & & $(0.334)$ & $(0.340)$ \\
\hline PROFIT & (1) & (2) & (3) & (4) \\
\hline HIGH-SCHOOL GRADUATE & & & $0.869 * *$ & 0.355 \\
\hline$(0=$ OTHERS, $1=$ HS GRADUATE $)$ & & & $(0.369)$ & $(0.384)$ \\
\hline HIGHER-EDUCATION GRADUATE & & & $0.898^{*}$ & 0.286 \\
\hline$(0=$ OTHERS, $1=$ HE GRADUATE $)$ & & & $(0.503)$ & $(0.517)$ \\
\hline \multirow[t]{2}{*}{ CONSTANT } & $14.72 * * *$ & $14.91 * * *$ & $9.691 * * *$ & $12.93 * * *$ \\
\hline & $(0.344)$ & $(0.341)$ & $(1.412)$ & $(1.582)$ \\
\hline
\end{tabular}

(source: IFLS, author"s calculation)

Several empirical studies have denied the existence of a significant positive relationship between microcredit, microfinancing, and similar services to enterprises growth. Bateman and Chang (2012) revealed that if a business gets support from microfinance, then it tends to increase product quantity without calculating real market demand and that an increase in sales will not result in profit. Furthermore, business credit tends to be profitable, because employers do not consider labor costs and time. In line with these findings, McPherson and Rous (2010) and Atmadja, Su \& Sharma (2016) showed that access to credit was not a significant factor for small-enterprise growth (Atmadja, Sharma \& Su, 2018). 
Bateman and Chang (2012) criticized microfinancing in general, even though it does not only cover business financing but also micro savings, microinsurance, and other services. Thus, it cannot be ascertained in detail what types of services were criticized, and they cannot be directly compared to this study. To estimate the relationship of credit to enterprise growth, it is necessary to distinguish the types of financial services used by businesses and their purposes.

In Indonesia, there have been several empirical studies examining the effect of business credit from formal financial institutions on small-enterprise growth. Their results are in line with the results of this study. Those using Indonesian samples at the aggregate level also reveal estimates of positive relationships. Research from Shinozaki (2012) showed that if credit were to increase by $1 \%$, sales value would increase by $0.58 \%$ (Shinozaki, 2012). The study concluded that the use of business credit was a factor that could encourage enterprises performance

According to a report from the Bank Indonesia (2015), $\sim 60-70 \%$ of MSMEs in Indonesia did have not receive access to bank financing. In accordance with a report from TNP2K (2013), the main reason for this was that they were not interested in borrowing. This is certainly a factor that must be addressed by the government and other stakeholders.

Based on the results of our study, the government should not only increase access by increasing the number of branches of formal financial institutions, but they should also encourage micro-entrepreneurs to apply for business loans, such as through community business credit programs and ultra-micro credit. Thus far, however, these programs tend to not favor microenterprises as evidenced by mapping the credit distributions (Ministry of Finance, 2018).

\subsection{Regression Results: Effect of Market Access on Enterprise Performance}

In the market-access variable category, there are two sub-variables: road quality and distance to public transportation. Distance to public transportation has a negative sign, indicating that proximity to formal financial institutions results in greater opportunities for business performance. However, these results are statistically insignificant. This contrasts the results of the road quality variable regression, which aimed to estimate the significant positive effect on microenterprises profit. These results are in line with the results of empirical research from Obokoh \& Goldman
(2016), which revealed that the poor quality of road infrastructure negatively affects the profitability and performance of SMEs, owing to the high costs incurred by the SMEs in the distribution of finished goods.

The difference in the estimated regression between distance to public transportation and road quality to business performance indicates that the quality of infrastructure can better explain the relationship of market access to business performance compared to quantity. The estimation is similar to one a study conducted in Nairobi, which discussed the relationship of transportation infrastructure in the form of construction and maintenance of road quality to the performance of MSMEs. The study showed that there was a significant relationship between infrastructure development and small business performance (Ndiangui, 2012). This research further revealed that efficient transportation implies increased productivity, which allows entrepreneurs to become more competitive and expand their market. Limited physical infrastructure can therefore be a major cause of low investment levels and underdeveloped small-enterprise performance. Poor road networks increase the cost of logistics, making those MSMEs less competitive (Ndiangui, 2012). One of the interesting findings from that study showed that most small enterprises preferred to use road transportation rather than railroads or other modes, because costs were more expensive compared (Ndiangui, 2012). Thus, small enterprises often find it difficult to expand their markets. This can ultimately explain why the existence of public transportation facilities did not have significant effects.

Ndiaye, Razak, Nagayev, and Ng (2018) suggested policymaking to improve infrastructure. They recommended that the government provide adequate basic infrastructure, because most infrastructure could not be provided by the entrepreneurs. The infrastructure, in turn, must be able to support microenterprises logistics.

Campbell (1972) and Goodwin (2000) revealed that transportation was a key factor of production. Provision or improvement of road quality decreases transportation costs and travel time. From an aggregate point of view, better road quality encourages social and economic development, because it increases mobility and access to resources and markets (IFAD, 2012). The importance of road quality to micro-enterprises growth was further expressed by Gibson and Olivia (2010), who showed that limited access and poor quality road infrastructure slowed the growth of rural household enterprises in Indonesia. Additionally, business competitiveness in rural areas is strongly influenced by 
the quality of transportation infrastructure (Patterson \& Anderson, 2003).

The implication for policy is that the government and related stakeholders should take careful steps toward implementing intensive infrastructure development programs. Based on the results of our study, the development of public infrastructure not only could lead to the construction of new physical infrastructure, it could also result in the maintenance and improvement to the quality of infrastructure.

\subsection{Regression Results: Effect of Location and Characteristics of Households on Enterprises Performance}

Statistically, the age and education of the head of household significantly influence micro-enterprise performance. This is in line with several empirical studies that revealed that individual demographic characteristics (i.e., gender, age, education) were factors influencing business performance (Nichter \& Goldmark, 2009).

The age variable of the head of household shows a positive relationship on micro-enterprise performance. These results are in line with the findings of Rose, Kumar, \& Yen (2006), who revealed that there was a positive relationship between the age of the individual and business performance. However, the number of household members shows an insignificant relationship with performance. According to the results of Chrisman, Chua, and Litz (2003), which revealed that there was no significant difference in business growth between enterprises that employed household members and those that did not.

From the coefficient value, the higher-education variable had the highest value compared to other levels of education, implying that the higher the level of education of the head of the household, the greater the business performance. These findings are in line with the results of Kim, Aldrich, and Keister (2006), who revealed that there was a positive relationship between education levels and business growth.

Urban variables showed positive estimates, but they were statistically insignificant. In accordance with the results of research from Lee and Cowling (2012), we revealed that the decrease of rural MSME growth was not caused by geographical factors. They were instead caused by other enterprise characteristics.

The gender of the head of household did not show a statistically significant relationship, according to the results of research from Khalife and Chalouhi (2013), who revealed that no significant difference existed between female and male owners regarding business income. Instead, the difference in business income differences could be explained by factors related to the education level.

\section{CONCLUSION}

Based on our regression results, the distance to formal financial institutions did not significantly effect business profits, although the availability of business loans and their use significantly influenced microenterprise profits. In the category of market access, only the quality of roads significantly influenced micro-enterprises profits, whereas the distance to public transportation had no significant effect. These findings indicate that financial access or inclusion can affect the performance of a business if the entrepreneurs succeed in obtaining available financial services (e.g., business credit). Thus, the affordability of financial institutions is insufficient to cause micro enterprise growth. Thus, financial institutions should provide financial services that support the community, especially that driven by micro-entrepreneurs. The supply-side availability of business credit is expected to encourage business performance and growth. With the existence of business credit services that can be reached from household entrepreneurs, they will be encouraged apply for credit, because micro-enterprises having access to credit experience faster growth. From these results, new or updated policies should stress inclusion and financial access. The support provided could improve the pro-micro-enterprises program services that have been implemented by the government.

In terms of market access, the difference in the estimated regression between distance to public transportation and road quality to micro-enterprise performance indicates that the quality of infrastructure can well-explain the relationship of market access to micro-enterprise performance compared to quantity. Roads are key to this relationship. Provision or improvement of road quality will decrease transportation costs and travel times. From our results, policy recommendations can be taken, regarding the government's move to build better infrastructure followed by maintenance and quality improvement.

\section{RESEARCH LIMITATIONS}

Although the results of this study have answered the research questions, there were limitations that should be addressed by future studies. The sample 
coverage of this study only includes 2 years because of the current availability of IFLS data. Additionally, the study model was generalized and did not include other business aspects, such as informality, telecommunications facilities, and other aspects related to extant theory. Furthermore, the framework, modeling, and methodology should be further developed and tested.

\section{REFERENCES}

[1] American Psychological foundation of Canada. (2018) Survey of entrepreneurs and MSMES in Indonesia (1-42).

[2] Atmadja, A. S., Sharma, P. and Su, J. (2018). „Microfinance and microenterprise performance in Indonesia: an extended and updated surveyee. International Journal of Social Economics, 45(6), pp. 957-972. https://doi.org/10.1108/IJSE-022017-0031.

[3] Atmadja, A. S., Su, J. and Sharma, P. (2016). „Examining the impact of microfinance on microenterprise performance (implications for women-owned micro enterprises in Indonesia) ${ }^{\text {ce }}$. International Journal of Social Economics, 43(10), pp. 1-22.

[4] Bank Indonesia 2015 Profil bisnis usaha mikro, kecil dan menengah (umkm).

[5] Bateman, M. and Chang, H. (2012). „Microfinance and the illusion of development evelopmhubris to nemesis in thirty years $1^{\mathrm{ee}}$. World Economic Review, 1, pp. 13-36.

[6] Campbell, T. C. (1972). „Transport developing and impact countries its in ${ }^{e e}$. Transportation Journal, 12(1), pp. 15-22.

[7] Carton, R. B. (2004). „Measuring organizational performance: an exploratory studye ${ }^{\text {ec }}$ The Journal of American Academy of Business, pp. 68-71.

[8] Carton, R. B. and Hofer, C. W. (2010). „Organizational financial performance eridentifying and testing multiple dimensions ${ }^{e e}$. Academy of Entrepreneurship Journal. 16(1), pp. 1-22.

[9] Chrisman, J. J., Chua, J. H. and Litz, R. (2003). „A unified systems perspective of family firm performance: an extension and integration ${ }^{\text {ee }}$. Journal of Business Venturing, 18(4), pp. 467472. https://doi.org/10.1016/S08839026(03)00055-7.
[10] Demirgüç-Kun, A., Beck, T. and Honohan, P. 2008 Finance for all?: policies and pitfalls in expanding access. The World Bank, Washington.

[11] Gibson, J. and Olivia, S. (2010). „The effect of infrastructure access and quality on Non-Farm Enterprises in Rural Indonesia ${ }^{e e}$ World Development, 38(5), pp. 717-726. https://doi.org/10.1016/j.worlddev.2009.11.010.

[12] Goodwin, F. 2000 Transport, Infrastructure and the Economy bad value to European tax payers.

[13] Hudson, M., Smart, A. and Bourne, M. (2001). „Theory and practice in SME performance measurement systems ${ }^{\text {ee }}$. International Journal of Operations and Production Management, 21(8), pp.

1096-1115. https://doi.org/10.1108/EUM0000000005587.

[14] Indonesia Ministry of Cooperatives and SMEs, "Perkembangan data usaha mikro, kecil, menengah (umkm) dan usaha besar (ub) tahun 2016 - 2017," 2017.

[15] International financial Coorporation, "MSME finance gap.” World Bank. 2017

[16] International Fund for agriculture development 2012 Access to markets: making value chains work for poor rural people.

[17] Kementerian Keuangan. PROGRAM PEMBIAYAAN ULTRA MIKRO (PEMBIAYAAN Umi), 2018.

[18] Khalife, D. and Chalouhi, A. (2013). „Gender and business performance'. International Strategic Management Review, 1(1-2), pp. 1-10.

[19] Kim, P. H., Aldrich, H. E. and Keister, L. A. (2006). „Access (not) denied the impact of financial, human, and cultural capital on entrepreneurial entry in the United States *ee. Small Business Economics, 27(1), pp. 5-22. https://doi.org/10.1007/s11187-006-0007-X.

[20] Lee, N. and Cowling, M. (2013). „Place, sorting effects and barriers to enterprise in deprived areas: different problems or different firms ?e International Small Business Journal: Researching Entrepreneurship, 31(8), pp. 914-937. https://doi.org/10.1177/0266242612445402.

[21] Michael A. McPherson and Jeffrey J. Rous (2010). „Access to finance and small enterprise growth roevidence From east Java ${ }^{e e}$. The Journal 
of Developing Areas, 43(2), pp. 159-172. https://doi.org/10.1353/jda.0.0066.

[22] Mirmulstein, M. L. "MSME Country Indicators 2014, 2014

[23] Murphy, G. B., Trailer, J. W. and Hill, R. C. (1996). „Measuring performance in entrepreneurship research". Journal of Business Research, 36(1), pp. 15-23. https://doi.org/10.1016/0148-2963(95)00159-X.

[24] Ndiangui, J. M. 2012 Transportation as a determinant of small and medium. University of Nairobi, Nairobi.

[25] Ndiaye, N., Abdul Razak, L. A., Nagayev, R. and $\mathrm{Ng}$, A. (2018). „Demystifying small and medium enterprises (SMEs) performance in emerging and developing economies". Borsa Istanbul Review, 18(4), pp. 269-281. https://doi.org/10.1016/j.bir.2018.04.003.

[26] Nichter, S. and Goldmark, L. (2009). „Small firm growth in developing countries". World Development, 37(9), pp. 1453-1464. https://doi.org/10.1016/j.worlddev.2009.01.013.

[27] Obokoh, L. O. and Goldman, G. (2016). „Infrastructure deficiency and the performance of small- and medium-sized enterprises in Nigeriae $s$ Liberalised Economy Acta Commer. - Indep"e. Res. Journal of Management Sciences, 16(1), pp. $1-10$.
[28] organization for economic co-operation and development. „Small, medium, stronge. Trends in SME Performance and Business Conditions. OECD Publishing, Paris 2017.

[29] Patterson, H. and Anderson, D. (2003). „What is really different about rural and urban firms? Some evidence from Northern Ireland ${ }^{\text {ee }}$. Journal of Rural Studies, 19(4), pp. 477-490. https://doi.org/10.1016/S0743-0167(03)00027-5.

[30] Riwayati, H. E. (2017). Financial inclusion of business players in mediating the success of small and Medium Enterprises in Indonesiae. International Journal of Economics and Financial Issues, 7(4) pp. 623-627.

[31] Rose, R. C., Kumar, N. and Yen, L. L. (2006). "The dynamics of entrepreneurs" success factors in influencing venture growth"e. Journal of Asia Entrepreneurship and Sustainability, II(3), pp. 119.

[32] Shinozaki, S. 2012 ADB working paper series on regional economic integration, 104.

[33] Sridhar, K. S. and Wan, G. (2010). „China Economic Review Firm location choice in cities : evidence from China, India, and Brazile. China Economic Review, 21(1), pp. 113-122. https://doi.org/10.1016/j.chieco.2009.11.003.

[34] TNP2K, "Branchless banking untuk meningkatkan financial inclusion, 2013 